\title{
Free Energy of Hydration of Niobium Oxide
}

by

M. J. Plodinec

Westinghouse Savannah River Company

Savannah River Site

Aiken, South Carolina 29808

DOE Contract No. DE-AC09-96SR18500

This paper was prepared in connection with work done under the above contract number with the U.S. Department of Energy. By acceptance of this paper, the publisher and/or recipient acknowledges the U. S. Government's right to retain a nonexclusive, royalty-free license in and to any copyright covering this paper, along with the right to reproduce and to authorize others to reproduce all or part of the copyrighted paper. 


\section{DISCLAMIER}

Portions of this doeument may be illegible in electronic image products. Images are produced from the best available original documert. 


\section{DISCLAIMER}

This report was prepared as an account of work sponsored by an agency of the United States Government. Neither the United States Government nor any agency thereof, nor any of their employees, makes any warranty, express or implied, or assumes any legal liability or responsibility for the accuracy, completeness, or usefulness of any information, apparatus, product, or process disclosed, or represents that its use would not infringe privately owned rights. Reference herein to any specific commercial product, process, or service by trade name, trademark, manufacturer, or otherwise does not necessarily constitute or imply its endorsement, recommendation, or favoring by the United States Government or any agency thereof. The views and opinions of authors expressed herein do not necessarily state or reflect those of the United States Government or any agency thereof.

This report has been reproduced directly from the best available copy.

Available to DOE and DOE contractors from the Office of Scientific and Technical Information, P.O. Box 62, Oak Ridge, TN 37831; prices available from (615) 576-8401.

Available to the public from the National Technical Information Service, U.S. Department of Commerce, 5285 Port Royal Road, Springfield, VA 22161. 
Keywords: Niobium oxide, glass, hydration, thermodynamics

Retention period: Permanent

cc: E. W. Holtzscheiter, 773-A

E. F. Duhn, 773-A

N. E. Bibler, 773-A

W. G. Ramsey, 773-A

D. F. Bickford, 773-43A

K. M. Marshall, 773-43A

J. C. Marra, 773-43A

J. M. Pareizs, 773-A

T. F. Meaker, 773-A

J. R. Harbour, 773-43A

M. K. Andrews, 773-A

T. L. Fellinger, 773-A

O. B. Hodoh, 773-A

D. A. Crowley, 773-43A

C. M. Jantzen, 773-A

D. K. Peeler, 773-A

R. F. Schumacher, 773-43A

C. T. Randall, 704-T

K. G. Brown, 704-1T

W. E. Daniel, 704-1T

Records (4), 773-52A

August 21, 1996

TO: $\quad$ E. W. HOLTZSCHEITER

FROM: M. J. PLODINEC IX'

FREE ENERGY OF HYDRATION OF NIOBIUM OXIDE (U)
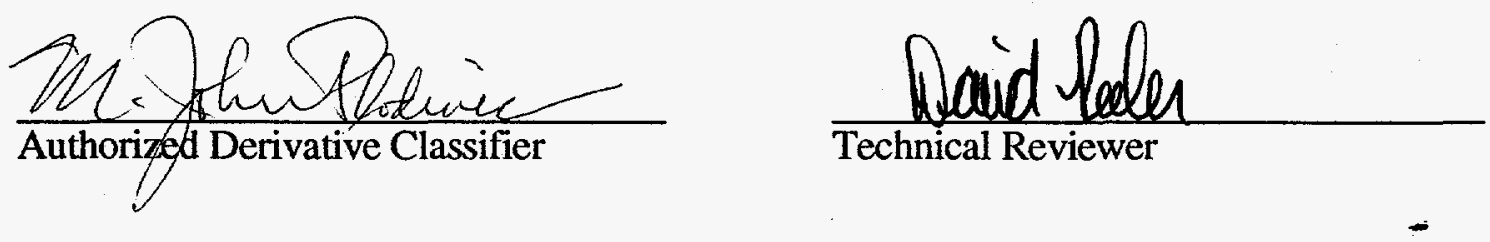


\section{FREE ENERGY OF HYDRATION OF NIOBIUM OXIDE (U)}

\section{SUMMARY}

Some of the glasses being formulated by SRTC researchers contain niobium oxide. In this report, the free energy of hydration of the oxide is calculated $\left(\Delta \mathrm{G}^{\circ}{ }_{\text {hydration }}=+12.26 \mathrm{~kJ} / \mathrm{mol}\right.$, or $+2.93 \mathrm{kcal} / \mathrm{mol}$ ), from the free energies of formation of the oxide, the hydroxide, and water. This value can be used in calculations of the free energy of hydration of glasses containing niobium.

\section{CALCULATION}

There is very little information about niobium in glass, primarily due to its rarity and cost. Potentially, niobium could exist as either $\mathrm{Nb}_{2} \mathrm{O}_{3}, \mathrm{NbO}_{2}$, or $\mathrm{Nb}_{2} \mathrm{O}_{5}$ in borosilicate glasses. However, based on the discussion in Volf, 1 it is clear that the +5 oxide is much more likely to be the form in glass. This is supported by the aqueous chemistry of $\mathrm{Nb}$, where $\mathrm{Nb}+4$ is not stable in aqueous environments, and $\mathrm{Nb}+3$ is only stable at low $\mathrm{Eh}$ and $\mathrm{pH} .2,3$ Thus, the calculation has been based on $\mathrm{Nb}_{2} \mathrm{O}_{5}$.

The hydration reaction is

$$
\mathrm{Nb}_{2} \mathrm{O}_{5}+5 \mathrm{H}_{2} \mathrm{O} \Leftrightarrow 2 \mathrm{Nb}(\mathrm{OH})_{5}
$$

The free energies of formation of the reactants and product are 4

$$
\begin{array}{cc}
\text { Compound } & \Delta \mathrm{G}_{\mathrm{f}}^{\circ}(\mathrm{kJ} / \mathrm{mol}) \\
\mathrm{Nb}_{2} \mathrm{O}_{5} & -1766.0 \\
\mathrm{H}_{2} \mathrm{O} & -228.572 \\
\mathrm{Nb}(\mathrm{OH})_{5} & -1448.3
\end{array}
$$

Thus, the free energy of the hydration reaction is $2 \times(-1448.3)-5 \times(-228.572)-(-1766.0)$ $\mathrm{kJ} / \mathrm{mol}$, or $+12.26 \mathrm{~kJ} / \mathrm{mol}$. Dividing by $4.184 \mathrm{~kJ} / \mathrm{kcal}$ yields a value of $+2.93 \mathrm{kcal} / \mathrm{mol}$. This value should be used for calculations of the free energy of hydration of glasses.

\section{REFERENCES}

1. M. B. Volf, Chemical Approach to Glass, Elsevier, 303-5 (1984).

2. D. G. Brookins, Eh-pH Diagrams for Geochemistry, Springer, 110-11 (1983).

3. R. M. Garrels, C. L. Christ, Solutions, Minerals, and Equilibria, Harper and Row, 417 (1976).

4. D. D. Wagman, et al., The NBS tables of chemical thermodynamic preperties, published as Supplement No. 2 to the J. Phys. and Chem. Reference Data, 11, p. 2-207 